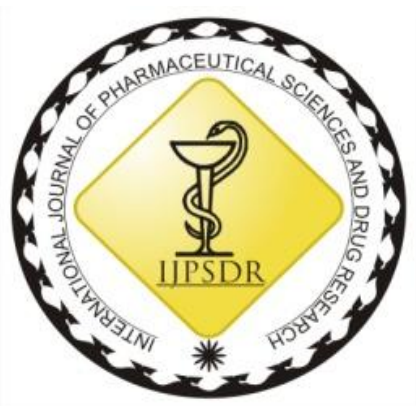

ISSN: 0975-248X

RESEARCH ARTICLE CODEN (USA): IJPSPP (cc) EY-NC-SA

\title{
Attenuation of Diabetic Nephropathy in Streptozotocin Induced Diabetic Rats by Methanolic Extract of Bougainvillea spectabilis Aerial Parts
}

\author{
N.V.L Suvarchala Reddy V*, M. Ganga Raju, B. Alekhya, C.V.S Subrahmanyam \\ Department of Pharmacology, Gokaraju Rangaraju College of Pharmacy, Hyderabad, Telangana, India
}

Copyright (C) 2019 N.V.L Suvarchala Reddy V et al. This is an open access article distributed under the terms of the Creative Commons Attribution-NonCommercial-ShareAlike 4.0 International License which allows others to remix, tweak, and build upon the work noncommercially, as long as the author is credited and the new creations are licensed under the identical terms.

\begin{abstract}
Diabetic nephropathy has become a leading cause of end stage renal failure worldwide. To develop Complementary and Alternative Medicine for the treatment of diabetic nephropathy, the present study investigated the protective effects of methanolic extract of Bougainvillea spectabilis (MEBS) in streptozotocin-induced diabetic nephropathy. In this study, diabetes was induced by a single injection of streptozotocin (STZ, $45 \mathrm{mg} / \mathrm{kg}$, i.p.) in rats. STZ diabetic rats were treated with oral doses of MEBS (200 and $400 \mathrm{mg} / \mathrm{kg}$ ) for 8 weeks. At the end of the experimental period body, kidney weight, blood glucose levels, serum and urine parameters were investigated. Antioxidant enzymes and lipid peroxide levels were determined in the kidney along with histopathological examination of the same. MEBS significantly increased body weight, lowered blood glucose levels and ameliorated kidney hypertrophy index in the STZ-diabetic rats. The extract also decreased the levels of creatinine, blood urea nitrogen, total cholesterol, triglycerides, advanced glycation end products and albumin in serum and urine, respectively. MEBS significantly increased the antioxidant parameters in the kidney. Histological evaluation revealed that MEBS treated STZ-diabetic rats demonstrated reduced vacuolar degeneration of tubules; periodic acid Schiff base (PAS) positivity staining intensity in glomeruli and basement membrane thickening. Present findings provide experimental evidence that MEBS has potential antioxidant, antihyperglycemic and anti-glycation activities which might be helpful in slowing the progression of diabetic nephropathy.
\end{abstract}

Keywords: Diabetic nephropathy, Streptozotocin, Bougainvillea spectabilis.

DOI: 10.25004/IJPSDR.2019.110103

Int. J. Pharm. Sci. Drug Res. 2019; 11(1): 16-21

*Corresponding author: Dr. N.V.L Suvarchala Reddy V

Address: Department of Pharmacology, Gokaraju Rangaraju College of Pharmacy, Bachupally, Hyderabad, Telangana, India

Tel.: +91-9000811806

E-mail $\bowtie$ : suvarchalakiran@gmail.com

Relevant conflicts of interest/financial disclosures: The authors declare that the research was conducted in the absence of any commercial or financial relationships that could be construed as a potential conflict of interest.

Received: 30 October, 2018; Revised: 17 December, 2018; Accepted: 28 December, 2018; Published: 20 January, 2019

\section{INTRODUCTION}

Diabetic nephropathy is characterized by structural as well as functional abnormalities. [1] Poor glycaemic control and accumulation of advanced glycation end products (AGEs) play a significant role in the development of diabetic nephropathy. Furthermore, advanced glycation end products have been implicated in tissue damage associated with diabetic nephropathy. The clinical and pathological hallmarks of diabetic nephropathy include urinary albumin excretion along 
with accumulation of extracellular matrix, thickening of basement membranes, mesangial expansion, hypertrophy and glomerular epithelial cell (podocyte) loss within the glomeruli. [2] Patients with diabetic nephropathy have a progressive decline in glomerular function. [3] Antihypertensive agents, particularly those targeting the renin angiotensin system, such as angiotensin converting enzyme inhibitors, angiotensin receptor-1 antagonists are reported to be the most effective treatments for progressive diabetic nephropathy, to date. However, these treatments are not capable of preventing the onset of diabetic nephropathy.

Medicinal plants play a significant role in the development of potent therapeutic agents. Herbal medicines have been used to treat various human diseases. Moreover, the demand for herbal medicines is increasing day by day. Bougainvilleas are very popular and attractive ornamental plants in most areas with warm climates. The genus Bougainvillea from Nyctaginaceae family is a native of South America and commonly known as "paper flower" due to its bracts which are thin and papery. It is used as an antidiabetic, anti-inflammatory, antioxidant, antifertility potential, antibacterial, antiviral, and larvicidal. Bougainvillea spectabilis extract has been found to be highly effective in managing diabetic complications such as hyperlipidemia and thus, prevent the defects in lipid metabolism. [4] Further, the methanolic extract of Bougainvillea spectabilis has shown a promising role as an anti-obesity agent in the high fat diet induced obesity model. [5] Taking all this into consideration, the objective of the present study was to assess the protective effects of methanolic extract of Bougainvillea spectabilis (MEBS) in streptozotocin (STZ)-induced diabetic nephropathy.

\section{MATERIAL AND METHODS}

\section{Preparation of plant extract}

The leaves were washed with distilled water, shade dried and made into a coarse powder. The powder was initially defatted methanol using Soxhlet apparatus. The extract obtained was concentrated under reduced pressure using rotary evaporator (yield 21.8\%) and stored in an airtight container for subsequent use.

\section{Preliminary phytochemical screening}

The phytochemical investigation of Methanolic extract of Bougainvillea spectabilis was carried out following the standard procedure.

\section{Experimental}

\section{Animals}

Healthy male Albino rats weighing between 250 and $300 \mathrm{~g}$ were housed in polypropylene cages at ambient temperature of $22 \pm 1^{\circ} \mathrm{C}$ and relative humidity of 50 $60 \%$ with a $12 \mathrm{~h}$ light/dark cycle in registered animal house (CPCSEA). The animal experiments were carried out as per the guidelines of the Committee for the Purpose of Control and Supervision of Experiments on Animals (CPCSEA), India and approved by the
Institutional Animal Ethics Committee (IAEC) (Approval No: 1175/PO/Re/S/08/CPCSEA, 28/04/2017). Throughout the experimental period, the animals were fed with standard pellet diet and water ad libitum.

Experimental design

Diabetes was induced by a single injection of streptozotocin (STZ, $45 \mathrm{mg} / \mathrm{kg}$, i.p. freshly prepared in $0.1 \mathrm{M}$ citrate buffer $\mathrm{pH} 4.5)$ in rats. The control group received equal volume of vehicle $(0.1 \mathrm{M}$ citrate buffer, $\mathrm{pH}$ 4.5). Blood glucose level was measured from retro orbital plexus seven days after induction. Rats with blood glucose level above $14 \mathrm{mmol} / \mathrm{L}$ were considered as diabetic and were used for further study by initiating the treatment. MEBS was administered daily to rats per oral for 8 weeks. The animals were divided into 5 groups: Normal control group, STZ-induced diabetic group, STZ-induced diabetic group treated with MEBS $200 \mathrm{mg} / \mathrm{kg}$, STZ induced diabetic group treated with MEBS $400 \mathrm{mg} / \mathrm{kg}$ and STZ-induced diabetic group standard with metformin $100 \mathrm{mg} / \mathrm{kg}$. Metformin is globally accepted as the first choice in practically all therapeutic algorithms for diabetic subjects. The advantages of metformin are low risk of hypoglycaemia, modest weight loss, effectiveness and low cost. Data of UKPDS indicate that treatment based on metformin results in less total as well cardiovascular mortality. Many diabetologists as well as practitioners are fear to use metformin in patients with renal problems even if they have only albuminuria. There is a lot of confusion about the real restriction of its use in patients with CKD. [6]

The two doses of extract were selected on the basis of the acute oral toxicity study reported in the literature and also followed the criteria given by Butterveck and Nahrstedt 2012. [7] Blood glucose levels were measured before treatment and on $1^{\text {st }}, 2^{\text {nd }}, 4^{\text {th }}, 6^{\text {th }} \& 8^{\text {th }}$ weeks respectively. Body weight of each animal was determined at the initiation and end of the study. On the completion of 8 weeks, blood was withdrawn via retro orbital plexus. Blood samples were centrifuged at $1300 \mathrm{~g}$ for separation of serum and stored at $20^{\circ} \mathrm{C}$ until assay. After the experimental protocol all animals were sacrificed by cervical dislocation and biochemical studies were conducted on serum of experimental animal in each group. ${ }^{[8]}$

\section{Biochemical estimation}

Blood samples for the measurement of blood chemistry were drawn into prechilled EDTA-containing tubes and immediately placed on ice. Blood samples were centrifuged at $2300 \mathrm{~g}$ for separation of serums and stored at $-70^{\circ} \mathrm{C}$ until assay. Serums were used for the estimation of glucose, $24 \mathrm{~h}$ urea protein, blood urea nitrogen (BUN), and creatinine as described previously. [9] The levels of serum triacylglycerol (TG), total cholesterol (TC), high density lipoprotein (HDL), and low density lipoprotein (LDL) were measured as previously described. [10] Lipids in livers such as TC 
and TG were also estimated by the above-mentioned methods.

\section{Kidney antioxidant parameters}

Kidney homogenate $(10 \%, \mathrm{w} / \mathrm{v})$ was prepared with 0.1 $\mathrm{M}$ PBS and centrifuged at $12000 \mathrm{~g}$ for $10 \mathrm{~min}$. The supernatant was used to determine superoxide dismutase (SOD) activity and Malondialdehyde (MDA) levels with commercially available kits.

\section{Kidney histopathological examination}

Kidney tissues were immediately preserved in $10 \%$ neutral buffered formalin, dehydrated through graded alcohol series, embedded in paraffin, cut into $5 \mathrm{~mm}$ sections and stained with hematoxylin and eosin (H\&E) and periodic acid Schiff base (PAS) method. The slides were examined by light microscopy under 400x magnifications for microscopic alterations of pathological significance.

Table 1: Effect of methanolic extract of Bougainvillea spectabilis on body weight and kidney weight and kidney hypertrophy

\begin{tabular}{cccc}
\hline Groups & $\begin{array}{c}\text { Body weight } \\
(\mathbf{g})\end{array}$ & $\begin{array}{c}\text { Kidney weight } \\
\mathbf{( g )}\end{array}$ & $\begin{array}{c}\text { Kidney hypertrophy } \\
\text { (kidney wt/ body } \\
\text { wt) } \%\end{array}$ \\
\hline $\begin{array}{c}\text { Normal } \\
\text { Disease control } \\
\text { MEBS }\end{array}$ & $230.5 \pm 0.76$ & $1.25 \pm 0.14$ & 0.54 \\
$(200 \mathrm{mg} / \mathrm{kg})$ & $250.5 \pm 0.78^{*} \mathrm{a}$ & $1.35 \pm 0.10^{*} \mathrm{a}$ & 0.92 \\
$\begin{array}{c}\mathrm{MEBS} \\
(400 \mathrm{mg} / \mathrm{kg})\end{array}$ & $245.6 \pm 0.88^{* *} \mathrm{~A}$ & $1.29 \pm 0.13^{*} \mathrm{a}$ & 0.54 \\
$\begin{array}{c}\text { Standard } \\
\text { metformin }\end{array}$ & $230.5 \pm 0.61^{*} \mathrm{a}$ & $1.24 \pm 0.15^{*} \mathrm{a}$ & 0.53 \\
$(100 \mathrm{mg} / \mathrm{kg})$ & & & 0.54 \\
\hline
\end{tabular}

Values are expressed as Mean \pm SEM, $(n=6)$. Statistical analysis was performed by using ANOVA followed by Dunnett's test. Results were compared with control group $\left(* *=p<0.01,{ }^{*}=p<0.05\right)$, negative control $(\mathrm{A}=p<0.01)$ and standard $(\mathrm{a}=p<0.01)$.

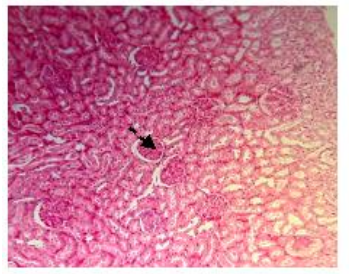

A. Normal

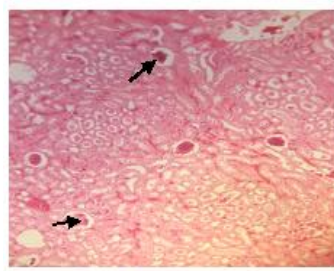

C. MEBS (200mg/kg)

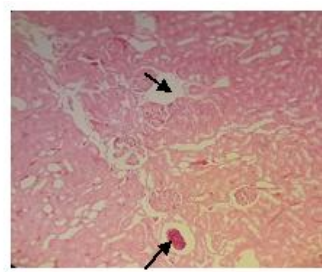

B. Disease control

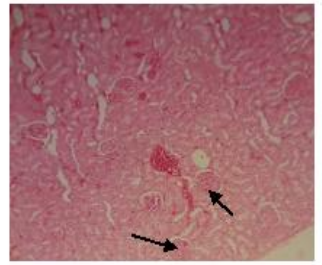

D. MEBS $(400 \mathrm{mg} / \mathrm{kg})$

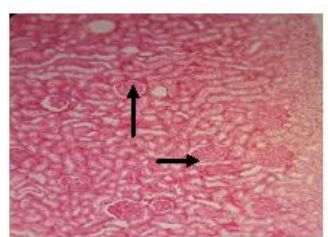

E. Standard metformin $(100 \mathrm{mg} / \mathrm{kg})$

Fig. 1: Photomicrographs of kidney (Hematoxylin and Eosin staining under a light microscope at $400 x$ magnification). A: Control rats; B: STZ-diabetic rats; C: $200 \mathrm{mg} / \mathrm{kg}$ MEBS treated group; D: 400 $\mathrm{mg} / \mathrm{kg}$ MEBS treated group; E: $100 \mathrm{mg} / \mathrm{kg}$ Metformin standard group.

\section{RESULTS}

Preliminary phytochemical screening

The preliminary phytochemical screening carried out on MEBS revealed the presence of phytoconstituents such as presence of phenolic compounds, alkaloids, flavonoids, saponins, terpenoids, tannins, carbohydrates etc.

Body weight

During 8-week experiment, STZ-diabetic rats exhibited significant weight loss when compared with normal rats. At the end of 8 weeks treatment, the body weight of rats treated with MEBS at the dose of $200 \mathrm{mg} / \mathrm{kg}$ and $400 \mathrm{mg} / \mathrm{kg}$ was significantly increased compared with the diabetic control group (Table 1).

Kidney weight and kidney hypertrophy

The kidney weight and kidney hypertrophy index in STZ diabetic rats were significantly increased as compared to those in the normal control group. Treatment of STZ-diabetic rats with MEBS at the dose of $200 \mathrm{mg} / \mathrm{kg}$ and $400 \mathrm{mg} / \mathrm{kg}$ ameliorated kidney hypertrophy index (Table 1).

Blood glucose levels

Administration of STZ led to significant increase in fasting blood glucose levels in the diabetic group as compared to the normal control group throughout 8 weeks after induction. Furthermore, STZ-diabetic rats treated with $200 \mathrm{mg} / \mathrm{kg}$ and $400 \mathrm{mg} / \mathrm{kg}$ MEBS showed a significant decrease in the fasting blood glucose levels at the end of 6 weeks (Table 2).

Serum and urine parameters

The STZ-diabetic rats showed a significant decrease in the level of creatinine in urine as compared to the normal control group. After treatment with MEBS, the creatinine content increased significantly in urine. The STZ-diabetic rats showed a significant increase in the albumin content in urine, as compared to the normal group. The albumin level of the STZ-diabetic rats treated with MEBS was brought back to normal. The STZ-diabetic rats exhibited significant increase in the blood urea nitrogen content whereas treatment with MEBS significantly decreased this level. In STZ-diabetic rats a significant increase in the level of serum triglycerides and cholesterol was observed as compared to the normal control group. However, STZ-diabetic rats treated with MEBS demonstrated a significant decrease in the level of triglycerides and cholesterol (Tables 3 and 4).

Kidney antioxidant parameters

Significantly higher levels of Malondialdehyde (MDA) (a marker of lipid peroxidation) were detected in the kidney of STZ-diabetic rats. SOD, CAT and GSH activities were significantly decreased in the kidney of STZ-diabetic rats as compared to the normal control rats. Treatment with MEBS significantly decreased the increased level of MDA at the dose of 200 and 400 $\mathrm{mg} / \mathrm{kg}$ and significantly increased the decreased activities of SOD and GSH at all dose levels. Significant elevation of catalase activity was observed at the dose of $400 \mathrm{mg} / \mathrm{kg}$ of MEBS (Table 5). 
N.V.L Suvarchala Reddy V et al. / Attenuation of Diabetic Nephropathy in Streptozotocin Induced Diabetic.....

Table 2: Effect of methanolic extract of Bougainvillea spectabilis on blood glucose levels

\begin{tabular}{|c|c|c|c|c|c|c|}
\hline \multirow{2}{*}{ Groups } & \multirow{2}{*}{$\begin{array}{c}\text { After } \\
\text { Induction }\end{array}$} & \multicolumn{5}{|c|}{ Blood Glucose Levels (mg/dL) } \\
\hline & & $1^{\text {st }}$ week & $2^{\text {nd }}$ week & $4^{\text {th }}$ week & $6^{\text {th }}$ week & $8^{\text {th }}$ week \\
\hline Normal control & $91.6 \pm 0.80$ & $92.6 \pm 0.94$ & $93.8 \pm 0.94$ & $96 \pm 0.966$ & $97.3 \pm 0.88$ & $97.5 \pm 0.763$ \\
\hline Negative control & $250 \pm 0.96^{* *} \mathrm{~A}$ & $320 \pm 0.99 * * \mathrm{Aa}$ & $329 \pm 0.96^{* *} \mathrm{Ab}$ & $335 \pm 0.99^{*} \mathrm{~A}$ & $340 \pm 0.94^{* *} \mathrm{Aa}$ & $347 \pm 0.97 * * a B$ \\
\hline MEBS (200 mg/kg) & $242.6 \pm 0.8^{* *} \mathrm{Aa}$ & $203.5 \pm 0.76^{* *} \mathrm{Aa}$ & $198.6 \pm 0.88^{* *} \mathrm{Ab}$ & $185.8 \pm 0.945^{* *} \mathrm{Aa}$ & $179.5 \pm 0.763^{* *} \mathrm{AB}$ & $174.6 \pm 0.88^{* *} \mathrm{AB}$ \\
\hline MEBS (400 mg/kg) & $242.5 \pm 0.7^{* *} \mathrm{a}$ & $209.8 \pm 0.945^{* *} \mathrm{AB}$ & $184.5 \pm 0.763^{* *} \mathrm{AB}$ & $168.6 \pm 0.88^{* *} \mathrm{AB}$ & $143.8 \pm 0.945^{*} \mathrm{Bb}$ & $139.6 \pm 0.88^{*} \mathrm{Aa}$ \\
\hline $\begin{array}{l}\text { STD Metformin } \\
(100 \mathrm{mg} / \mathrm{kg})\end{array}$ & $238.8 \pm 0.7^{*} \mathrm{~B}$ & $204 \pm 0.966^{* *} \mathrm{AB}$ & $187.8 \pm 0.94^{*} \mathrm{~B}$ & $166 \pm 0.966^{*} b$ & $154 \pm 0.966^{* *} \mathrm{Aa}$ & $136.1 \pm 0.94^{* *} \mathrm{Bb}$ \\
\hline
\end{tabular}

Values are expressed as Mean \pm SEM, $(n=6)$. Statistical analysis was performed by using ANOVA followed by Dunnett's test. Results were compared with control group $\left(* *=p<0.01,{ }^{*}=p<0.05\right)$, negative control $(\mathrm{A}=p<0.01, \mathrm{~B}=p<0.05)$ and standard $(\mathrm{a}=p<0.01, \mathrm{~b}=p<0.05)$.

Table 3: Effect of methanolic extract of Bougainvillea spectabilis on Serum parameters

\begin{tabular}{|c|c|c|c|c|c|}
\hline Groups & $\begin{array}{c}\text { Serum } \\
\text { Albumin (mg/dL) }\end{array}$ & $\begin{array}{c}\text { Serum Creatinine } \\
(\mathrm{mg} / \mathrm{dL})\end{array}$ & $\begin{array}{c}\text { Blood urea } \\
\text { Nitrogen }(\mathrm{mg} / \mathrm{dL})\end{array}$ & $\begin{array}{c}\text { Total Cholesterol } \\
(\mathrm{mg} / \mathrm{dL})\end{array}$ & $\begin{array}{c}\text { Triglycerides } \\
(\mathrm{mg} / \mathrm{dL})\end{array}$ \\
\hline Control & $5.36 \pm 0.08$ & $1.75 \pm 0.09$ & $15.6 \pm 0.91$ & $58 \pm 0.96$ & $79 \pm 0.966$ \\
\hline Diabetic & $2.35 \pm 0.07^{* *}$ & $2.11 \pm 0.09^{* *}$ & $28.1 \pm 0.94^{* *}$ & $80.3 \pm 0.88^{*}$ & $153 \pm 0.945^{* *}$ \\
\hline $\begin{array}{c}\text { MEBS } \\
(200 \mathrm{mg} / \mathrm{kg})\end{array}$ & $3.58 \pm 0.09^{* *}$ & $0.88 \pm 0.094^{* *}$ & $22.6 \pm 0.98^{* *}$ & $71.5 \pm 0.76^{* *}$ & $122.3 \pm 0.88^{* *}$ \\
\hline $\begin{array}{c}\text { MEBS } \\
(400 \mathrm{mg} / \mathrm{kg})\end{array}$ & $4.55 \pm 0.07^{*}$ & $0.85 \pm 0.099^{* *}$ & $27 \pm 0.966^{*}$ & $62.8 \pm 0.94^{*}$ & $95.8 \pm 0.945^{* *}$ \\
\hline Metformin & $5 \pm 0.096^{*}$ & $1 \pm 0.096^{*}$ & $21.8 \pm 0.94^{* *}$ & $66 \pm 0.966^{*}$ & $83 \pm 0.966^{* *}$ \\
\hline
\end{tabular}

Values are expressed as Mean \pm SEM, $(n=6)$. Statistical analysis was performed by using ANOVA followed by Dunnett's test. Results were compared with control group $\left(* *=p<0.01,{ }^{*}=p<0.05\right)$, negative control $(\mathrm{A}=p<0.01, \mathrm{~B}=p<0.05)$ and standard $(\mathrm{a}=p<0.01, \mathrm{~b}=p<0.05)$.

Table 4: Effect of methanolic extract of Bougainvillea spectabilis on urine parameters

\begin{tabular}{ccc}
\hline Groups & $\begin{array}{c}\text { Urine creatinine } \\
\mathbf{g} / \mathbf{2 4 h}\end{array}$ & $\begin{array}{c}\text { Urine albumin } \\
\mathbf{g} / \mathbf{2 4 h}\end{array}$ \\
\hline Control & $22.5 \pm 0.76$ & $0.6 \pm 0.09$ \\
Diabetic & $13.1 \pm 0.94^{* *} \mathrm{~A}$ & $1.11 \pm 0.09^{* *} \mathrm{~A}$ \\
MEBS $(200 \mathrm{mg} / \mathrm{kg})$ & $15.5 \pm 0.76^{*} \mathrm{a}$ & $0.96 \pm 0.08^{*} \mathrm{a}$ \\
MEBS $(400 \mathrm{mg} / \mathrm{kg})$ & $17.6 \pm 0.88^{* *} \mathrm{~A}$ & $0.85 \pm 0.76^{* *} \mathrm{~A}$ \\
Metformin & $21.6 \pm 0.88^{* *} \mathrm{~A}$ & $0.7 \pm 0.94^{*} \mathrm{a}$ \\
\hline
\end{tabular}

Values are expressed as Mean \pm SEM, $(n=6)$. Statistical analysis was performed by using ANOVA followed by Dunnett's test. Results were compared with control group $\left({ }^{* *}=p<0.01,{ }^{*}=p<0.05\right)$, negative control $(\mathrm{A}=p<0.01, \mathrm{~B}=p<0.05)$ and standard $(\mathrm{a}=p<0.01, \mathrm{~b}=p<0.05)$.

Table 5: Effect of methanolic extract of Bougainvillea spectabilis on antioxidant parameters

\begin{tabular}{|c|c|c|c|c|}
\hline Groups & $\begin{array}{c}\text { Reduced } \\
\text { glutathione }\end{array}$ & $\begin{array}{c}\text { Superoxide } \\
\text { dismutase }\end{array}$ & Catalase & $\begin{array}{c}\text { Lipid } \\
\text { peroxidation } \\
\end{array}$ \\
\hline $\begin{array}{l}\text { Normal } \\
\text { control }\end{array}$ & $17.1 \pm 0.94$ & $3.5 \pm 0.09$ & $8.4 \pm 0.11$ & $4 \pm 0.09$ \\
\hline $\begin{array}{l}\text { Negative } \\
\text { control }\end{array}$ & $\begin{array}{c}7.5 \pm 0.76^{* *} \\
\mathrm{~A}\end{array}$ & $\begin{array}{c}2.0 \pm 0.08^{* *} \\
\mathrm{~A}\end{array}$ & $\begin{array}{c}4.03 \pm 0.12^{* *} \\
\mathrm{~A}\end{array}$ & $\begin{array}{c}10 \pm 0.06^{* *} \\
\text { aA }\end{array}$ \\
\hline $\begin{array}{l}\text { MEBS (200 } \\
\mathrm{mg} / \mathrm{kg})\end{array}$ & $\begin{array}{c}8.5 \pm 0.94^{* *} \\
\mathrm{~A}\end{array}$ & $\begin{array}{c}2.60 \pm 0.07^{* *} \\
\mathrm{aA}\end{array}$ & $\begin{array}{c}5.16 \pm 0.11^{* *} \\
\mathrm{aA}\end{array}$ & $\begin{array}{c}5.8 \pm 0.07^{*} \\
\mathrm{aB}\end{array}$ \\
\hline $\begin{array}{l}\text { MEBS (400 } \\
\mathrm{mg} / \mathrm{kg})\end{array}$ & $\begin{array}{c}9.9 \pm 0.96^{* *} \\
\text { B }\end{array}$ & $\begin{array}{c}2.9 \pm 0.09^{* *} \\
a\end{array}$ & $\begin{array}{c}5.6 \pm 0.11^{* *} \\
\mathrm{aA}\end{array}$ & $\begin{array}{c}6.11 \pm 0.09^{* *} \\
\mathrm{aB}\end{array}$ \\
\hline $\begin{array}{c}\text { STD } \\
\text { Metformin } \\
(100 \\
\mathrm{mg} / \mathrm{kg}) \\
\end{array}$ & $\begin{array}{c}13.5 \pm 0.96^{*} \\
\mathrm{a}\end{array}$ & $\begin{array}{c}3.10 \pm 0.09^{* *} \\
\mathrm{a}\end{array}$ & $\begin{array}{c}7.4 \pm 0.4^{* *} \\
\mathrm{~A}\end{array}$ & $\begin{array}{c}7.7 \pm 0.08^{* *} \\
\mathrm{a}\end{array}$ \\
\hline
\end{tabular}

Values are expressed as Mean \pm SEM, $(n=6)$. Statistical analysis was performed by using ANOVA followed by Dunnett's test. Results were compared with control group $\left({ }^{* *}=p<0.01,{ }^{*}=p<0.05\right)$, negative control $(\mathrm{A}=p<0.01, \mathrm{~B}=p<0.05)$ and standard $(\mathrm{a}=p<0.01, \mathrm{~b}=p<0.05)$.

\section{Histopathological evaluation}

Control rats did not show any abnormal morphological changes in H\&E and PAS stained kidney specimens. Normal architecture and glomerular size and basement membrane thickness were observed in case of control group. According to H\&E stained kidney specimens of STZ-diabetic rats, moderate to severe vacuolar degeneration of tubules and increased glomerular space was observed. MEBS significantly reduced vacuolar degeneration of tubules at $200 \mathrm{mg} / \mathrm{kg}$ and 400 $\mathrm{mg} / \mathrm{kg}$ dose levels. Kidneys stained with PAS exhibited moderate intensity PAS positivity in glomeruli and mild degree basement membrane thickening in the negative control group. Treatment with MEBS reduced the PAS positivity staining intensity in glomeruli at all dose levels and basement membrane thickening in STZdiabetic rats at $400 \mathrm{mg} / \mathrm{kg}$ dose level respectively (Fig. 1).

\section{DISCUSSION}

Diabetic nephropathy, a serious complication of diabetes mellitus, is the most common cause of end stage renal failure. About $15-25 \%$ of type 1 diabetes patients and $30-40 \%$ of patients with type 2 diabetes suffer from diabetic nephropathy. [11] In spite of the availability of therapeutic agents which retard the progression of diabetic nephropathy, there has been renewed interest in the use of herbal medicines in order to prevent the genesis of this complication.

Bougainvillea spectabilis deciduous plant, the leaves of which are rich in polyphenolic compounds including tannins and flavonoids has aroused great interest due to its antidiabetic potential which could be considered as a lead to further study the effect of this part of the planton diabetic complications such as nephropathy. ${ }^{112-}$ 13] Streptozotocin has been an agent of choice to induce experimental diabetes mellitus due to its ability to induce specific necrosis of the pancreatic beta cells resulting in degranulation and loss of capacity to secrete insulin. [14-15] Thus, in the present study, STZ was used for induction of diabetes in rats. Administration of STZ led to significant increase in blood glucose level which was lowered on treatment with MEBS thus confirming the antihyperglycemic activity of the extract as reported by earlier established studies.

Several reports have stated the diminished hypoglycaemic responses of extract due to the presence of reducing sugars which could give rise to free glucose 
after digestion that may tend to rise blood glucose levels in the face of the hypoglycaemic actions by the active hypoglycaemic agents. [16] STZ-induced diabetes is associated with significant reduction in the body weight due to hyperglycaemia, hypoinsulinemia, increased muscle wasting and loss of tissue proteins. ${ }^{[17]}$ The body weight of STZ-diabetic rats was progressively reduced and treatment with MEBS improved the body weight significantly, thus indicating prevention of muscle tissue damage caused due to hyperglycaemia.

Increase in the weight of kidney (hypertrophy) in proportion to the body weight is observed in STZinduced rats. Local alterations in the production of one or more growth factors such as over expression of transforming growth factor e beta 1 in the kidney especially in proximal convoluted tubules cells and glomerular mesangial cells are proposed in the development of renal hypertrophy. An increase in the rate of protein synthesis and/or decrease in the degradation of renal extracellular components might also lead to renal hypertrophy. MEBS treatment reduced kidney/body weight ratio, thus demonstrating reversal of kidney hypertrophy in STZ-diabetic rats.

Diabetes mellitus leads to fatty liver, hypercholesterolemia and hypertriglyceridemia. Moreover, elevated cholesterol levels are associated with diabetic nephropathy. ${ }^{[18]}$ These increased levels were reversed towards normal after treatment with MEBS, thus demonstrating its potential to improve lipid metabolism. Hypoalbuminaemia is considered as a strongest predictor of death in patients with renal failure. Albumin is by far the most abundant protein in nephrotic urine. ${ }^{[19]}$ In STZ-diabetic rats, serum albumin concentration was decreased significantly with an increase in the albumin levels in urine, thus demonstrating that albuminuria was related to deteriorating kidney function. Treatment with MEBS normalized these levels thus, exhibiting its beneficial role against microalbuminuria. Increased serum creatinine level and BUN along with decreased excretion of creatinine in the urine are indicators of the development of diabetic nephropathy. Reversal of these effects was observed in STZ-diabetic rats treated with MEBS. The formation of AGEs in renal tissue plays a crucial role in the development of diabetic nephropathy. The irreversible formation of AGEs affects proteins and lipids thus causing damage to the blood vessels and kidneys. [20] AGEs are found in almost all tissues examined from STZ-induced diabetic rats. Moreover, kidneys are more susceptible to AGE formation than other tissues. [21]

Hyperglycemia leads to increased production of reactive oxygen species (ROS) which are involved in the etiology of several diabetic complications including diabetic nephropathy. [22] MDA, a late-stage lipid oxidation by-product, is an important indicator of free radical induced lipid peroxidation. Increased MDA levels are found in mesangial cells, proximal tubule cells, plasma and renal cortex. Increased MDA levels were suppressed in STZ-diabetic rats treated with MEBS. In addition to this, STZ-diabetic rats treated with MEBS showed increased levels of GSH, SOD and catalase, thus suggesting the antioxidant capacity of MEBS. Even though two doses of the extract was studied there was no dose dependent reduction in the parameters suggesting that second dose is not therapeutically efficacious in reducing the altered conditions.

Histopathological examination of kidney sections of STZ-diabetic rats showed severe vacuolar degeneration of tubules, increased glomerular space, moderate intensity PAS positivity in glomeruli and basement membrane thickening. Treatment with MEBS significantly reduced the aforementioned alterations, thus demonstrating protective role in renal damage.

In the present investigation, administration of MEBS to STZ-diabetic rats decreased blood glucose level, normalized the cholesterol and triglycerides level, ameliorated the serum and urine parameters along with normalization of kidney antioxidant status. In summary, MEBS possesses antioxidant, antihyperglycemic, antihyperlipidemic activity, thus exhibiting a protective action in STZ-induced diabetic nephropathy. Moreover, further work is necessary to elucidate in detail the mechanism of action of MEBS at the cellular and molecular levels.

\section{ACKNOWLEDGEMENTS}

The authors are grateful to the Principal and the Management of the Gokaraju Rangaraju College of Pharmacy, for the constant support and encouragement during the course of the work.

\section{REFERENCES}

1. Forbes JM, Coughlan MT, Cooper ME. Oxidative stress as a major culprit in kidney disease in diabetes. Diabetes. 2008;57:1446-1454.

2. Horie K, Miyata T, Maeda K, Miyata S, Sugiyama S, Sakai $\mathrm{H}$, van Ypersole de Strihou C, Monnier VM, Witztum JL, Kurokawa K. Immunohistochemical colocalization of glycoxidation products and lipid peroxidation products in diabetic renal glomerular lesions. Implication for glycoxidative stress in the pathogenesis of diabetic nephropathy. Journal of Clinical Investigation. 1997;100:29953004 .

3. Lewis EJ, Hunsicker LG, Bain RP, Rohde RD. The effect of angiotensinconverting-enzyme inhibition on diabetic nephropathy. The collaborative study group. New England Journal of Medicine. 1993;329:1456-1462.

4. Das S, Barman S. Antidiabetic and antihyperlipidemic effects of ethanolic extract of leaves of Punica granatum in alloxaninduced non-insulin-dependent diabetes mellitus albino rats. Indian Journal of Pharmacology. 2012;44:219-224.

5. Adnyana IK, Sukandar EY, Yuniarto A, Finna S. Anti-obesity effect of the pomegranate leaves ethanol extract (Punica granatum L.) in high fat diet induced mice. International Journal of Pharmacy and Pharmaceutical Sciences. 2014;6:626-631.

6. Butterweck V, Nahrstedt A. What is the best strategy for preclinical testing of botanicals? A critical perspective. Planta Medica. 2012;78:747-754. 
7. Gong L, Goswami S, Giacomini KM, Altman RB, Klein TE. Metformin pathways: pharmacokinetics and pharmacodynamics. Pharmacogenet Genomics. 2012;22:820827.

8. Tikoo K, Bhatt DK, Gaikwad AB, Sharma V, and Kabra DG. Differential effects of tannic acid on cisplatin induced nephrotoxicity in rats. FEBS Letters. 2007;581(10): 2027-2035.

9. Yahagi $\mathrm{N}$, Shimano $\mathrm{H}$, Hasty $\mathrm{AH}$, Matsuzaka T, Ide T, Yoshikawa T, Amemiya-Kudo M, Tomita S, Okazaki H, Tamura Y, lizuka Y, Ohashi K, Osuga J, Harada K, Gotoda $\mathrm{T}$, Nagai R, Ishibashi S, Yamada N. Absence of sterol regulatory element-binding protein-1 (SREBP-1) ameliorates fatty livers but not obesity or insulin resistance in Lep(ob)/Lep(ob) mice. Journal of Biological Chemistry. 2002; 277(22):19353-19357.

10. Wu KK, Huan Y. Streptozotocin-induced diabetic models in mice and rats. Current Protocol Pharmacology. 2008;40:1-14.

11. Wang GG, Lu XH, Li W, Zhao X, Zhang C. Protective effects of luteolin on diabetic nephropathy in STZ-induced diabetic rats. Evidence Based Complementary and Alternative Medicine. 2011;2011:1-7.

12. Al-Muammar MN, Khan F. Obesity: the preventive role of the pomegranate (Punica granatum). Nutrition. 2012;28:595604.

13. Patel AN, Bandwane DD, Mhetre NK. Pomegranate (Punica granatum Linn.) leaves attenuate disturbed glucose homeostasis and hyperglycemia mediated hyperlipidemia and oxidative stress in streptozotocin induced diabetic rats. European Journal of Integrative Medicine. 2014;6:307-321.

14. Zafar M, Naqvi SN. Effects of STZ-induced diabetes on the relative weights of kidney, liver and pancreas in albino rats: a comparative study. International Journal of Morphology. 2010;28:135-142.

15. Lenzen S. The mechanisms of alloxan- and streptozotocininduced diabetes. Diabetologia. 2008;51:216-226.

16. Shewamene Z, Abdelwuhab M, Birhanu Z. Methanolic leaf extract of Otostegia integrifolia Benth reduces blood glucose levels in diabetic, glucose loaded and normal rodents. BMC Complementary and Alternative Medicine. 2015;15:1-7.

17. Cheng D, Liang B, Li Y. Antihyperglycemic effect of Ginkgo biloba extract in streptozotocin-induced diabetes in rats. Biomed Research International. 2013;2013:1-7.

18. Nesbitt KN. An overview of diabetic nephropathy. Journal of Pharmacy Practice. 2004;17: 75-79.

19. Viswanathan V, Snehalatha C, Kumutha R, Jayaraman M, Ramachandran A. Serum albumin levels in different stages of type 2 diabetic nephropathy patients. Indian Journal of Nephrology. 2004;14:89-92.

20. Sohn E, Kim J, Kim C, Lee YM, Jo K, Shin SD, Kim JH, Kim JS. The extract of Litsea japonica reduced the development of diabetic nephropathy via the inhibition of advanced glycation end products accumulation in $\mathrm{db} / \mathrm{db}$ mice. Evidence Based Complementary and Alternative Medicine. 2013;2013:1-9.

21. Niedowicz DM, Daleke DL. The role of oxidative stress in diabetic complications. Cell Biochemistry and Biophysics. 2005;43:289-330.

22. King GL, Loeken MR. Hyperglycemia-induced oxidative stress in diabetic complications. Histochemistry and Cell Biology. 2004;122:333-338.

HOW TO CITE THIS ARTICLE: Suvarchala Reddy V NVL, Ganga Raju M, Alekhya B, Subrahmanyam CVS. Attenuation of Diabetic Nephropathy in Streptozotocin Induced Diabetic Rats by Methanolic Extract of Bougainvillea spectabilis Aerial Parts. Int. J. Pharm. Sci. Drug Res. 2019; 11(1): 16-21. DOI: 10.25004/IJPSDR.2019.110103 